\title{
ANALISIS PEMASARAN KAYU HUTAN RAKYAT DI KABUPATEN BOGOR
}

\author{
The Analysis of Private Timber Marketing in Bogor District \\ Purwawangsa $\mathrm{H}^{1^{*}}$, Oktaviarini $\mathrm{M}^{1}$, dan Mutaqin $\mathrm{F}^{2}$
}

(Diterima 18 Januari 2021 /Disetujui 28 Mei 2021)

\begin{abstract}
The private forest is one of alternatives that played an important role in fulfillment of a need raw materials management industry wood and the needs of wood. Development of private forest can improve the people and land revenue increase productivity. Research conducted in sub-district Leuwisadeng, Cigudeg, and Jasinga shows that there are some marketing actors involved in marketing wood of the private forest of them are farmers, traders, and sawmill industries. The marketing of the three actors formed four marketing channels are grouped based marketing actors and average skidding distance. Channels that most efficient among fourth the channels is a channels II with the percentage of farmer's share as $46.93 \%$ and the ratio of $K / B$ by 5.45 . Types of plants most favored by farmers and consumers is the type of sengon it because sengon having a short, the age of harvest readily grows, and easy cultivation. The consumer likes kind of plant is because sengon have reachable prices, sengon not easily bad condition wood and widely available in market.
\end{abstract}

Key words: bogor, farmer's share, marketing efficiency rasio, private forest

\begin{abstract}
ABSTRAK
Hutan rakyat merupakan salah satu alternatif yang memegang peranan penting dalam pemenuhan kebutuhan bahan baku industri pengelolaan kayu dan kebutuhan kayu. Pembangunan hutan rakyat dapat meningkatkan pendapatan masyarakat dan meningkatkan produktivitas lahan. Penelitian yang dilakukan di Kecamatan Leuwisadeng, Cigudeg, dan Jasinga menunjukkan bahwa pelaku pemasaran yang terlibat dalam pemasaran kayu hutan rakyat diantaranya adalah petani, pedagang, dan industri penggergajian kayu. Pemasaran dari ketiga pelaku tersebut membentuk empat saluran pemasaran yang dikelompokkan berdasarkan pelaku pemasaran dan jarak penyaradan ratarata. Saluran yang paling efisien adalah saluran II dengan persentase farmer's share sebesar 46,93\% dan rasio efisiensi pemasaran (K/B) sebesar 5,45. Jenis tanaman yang paling disukai oleh petani dan konsumen adalah jenis sengon karena memiliki umur panen yang pendek, mudah tumbuh, dan budidaya yang mudah. Jenis tanaman yang disukai konsumen adalah sengon karena memiliki harga yang terjangkau, tidak mudah rusak dan banyak tersedia di pasaran.
\end{abstract}

Kata kunci: bagi hasil, Bogor, hutan rakyat, kayu, pemasaran

\footnotetext{
${ }^{1}$ Departemen Manajemen Hutan, Fakultas Kehutanan dan Lingkungan, IPB University

* Penulis korespondensi:

e-mail: handie79@apps.ipb.ac.id

${ }^{2}$ Lulusan Departemen Manajemen Hutan, Fakultas Kehutanan dan Lingkungan, IPB University
} 


\section{PENDAHULUAN}

Hutan rakyat adalah hutan yang dimiliki oleh rakyat dengan luas minimal 0.25 hektar dengan penutupan tajuk tanaman kayu-kayuan dan atau jenis tanaman lainnya lebih dari $50 \%$ dan atau pada tanaman tahun pertama dengan tanaman sebanyak minimal 500 tanaman per hektar. Usaha hutan rakyat dapat dikembangkan pada lahan milik atau lahan yang dibebani hak-hak lainnya di luar kawasan hutan yang memenuhi persyaratan untuk kegiatan hutan rakyat (Kementerian Kehutanan 2012).

Luas hutan rakyat di Kabupaten Bogor diperkirakan seluas 16.945 ha (Dinas Pertanian dan Kehutanan Kabupaten Bogor, 2012), sedangkan luasan hutan negara di Kabupaten Bogor seluas 74.521 ha. Beberapa penelitian telah menunjukan bahwa pengusahaan hutan rakyat telah memberikan manfaat sosial dan ekonomi (Irawanti et al, 2012); (Sari et al, 2018). Pesepsi masyarakat terhadap hutan rakyat juga positif dimana masyarakat memandang hutan rakyat mampu menjalankan fungsi ekonomi, sosial, dan ekologi dengan baik. Fungsi ekonomi ditunjukkan dengan adanya peningkatan pendapatan, fungsi ekologi ditunjukkan dengan kemampuan hutan rakyat dalam mencegah banjir dan tanah longsor, memunculkan sumber air, serta konservasi tanah. Fungsi sosial hutan rakyat ditunjukkan dengan adanya lapangan pekerjaan, ekowisata, dan peluang kerjasama.

Sifat dari hasil produksi hutan rakyat (kayu rakyat) di antaranya volume atau jumlahnya yang relatif kecil, letaknya yang tersebar pada kondisi topografi yang sulit, jauh dari konsumen/pabrik dan industri kayu lainnya, kualitas kayu yang relatif lebih rendah dibandingkan dengan kualitas yang diharapkan oleh konsumen dan waktu panen yang tidak menentu (Sugiharto dalam Rosnawati 2004). Berdasarkan penelitian Sukwika et al. (2016), permasalahan krusial pengusahaan hutan rakyat di Kabupaten Bogor terutama pada aspek ekologi, ekonomi, dan sosial, seperti masalah kondisi kemiskinan di sekitar hutan, pendapatan petani hutan rakyat, rendahnya posisi tawar petani hutan rakyat dalam aspek pemasaran dan pembangunan wilayah yang kurang berkembang.

Penelitian ini bertujuan untuk mengidentifikasi jenis kayu yang banyak diminati oleh pasar, mengidentifikasi saluran pemasaran yang terjadi pada pengusahaan kayu hutan rakyat dan menentukan saluran pemasaran yang paling efisien, serta mengidentifikasi pembagian keuntungan (sharing profit) pada pihak-pihak yang terlibat dalam pemasaran kayu hutan rakyat.

\section{METODE PENELITIAN}

\section{Waktu dan Tempat Penelitian}

Penelitian ini dilakukan di 3 kecamatan di wilayah Kabupaten Bogor yaitu Kecamatan Jasinga, Cigudeg, dan Leuwisadeng yang merupakan pusat kegiatan usaha hutan rakyat di Kabupaten Bogor. Penelitian dilakukan pada bulan September 2014 sampai dengan Oktober 2015.

\section{Alat dan Bahan}

Data yang dikumpulkan dalam penelitian ini meliputi data primer dan data sekunder. Data primer diperoleh melalui pengamatan dan wawancara secara langsung pada lembaga pemasaran terkait seperti petani hutan rakyat, pedagang pengumpul, dan pemilik industri penggergajian (sawmill). Data sekunder diperoleh melalui studi literatur yang berasal dari jurnal, buku, laporan kegiatan serta sumber lain yang relevan.

\section{Pengumpulan Data}

Pengumpulan data dilakukan melalui kegiatan wawancara terhadap petani yang memiliki hutan rakyat serta pelaku pemasaran lainnya seperti pedagang pengumpul dan pemilik industri penggergajian (sawmill). Penentuan responden petani hutan rakyat dilakukan secara snowball sampling, sedangkan pada industri penggergajian (sawmill) dipilih secara purposive sampling dengan pertimbangan keterwakilan jumlah dan kapasitas terpasang mesin penggergajian. Penentuan responden pedagang pengumpul dilakukan dengan teknik convenience sampling. Jumlah responden petani hutan rakyat berjumlah 30 orang dengan pembagian sebanyak 10 orang pada setiap kecamatan. Jumlah responden pelaku pemasaran lainnya sebanyak 10 orang yaitu pedagang pengumpul sebanyak 4 orang dan pemilik industri penggergajian (sawmill) sebanyak 6 orang dengan pembagian sebanyak 2 industri pada setiap kecamatan.

\section{Analisis Data}

Data yang diperoleh dianalisis secara kualitatif dan kuantitatif guna menjawab semua tujuan yang diinginkan.

\section{a. Analisis saluran pemasaran}

Saluran pemasaran dapat dianalisis dengan melakukan pengamatan terhadap pelaku pemasaran yang ada. Setiap pelaku pemasaran akan membentuk saluran pemasaran yang berbeda, yang akan mempengaruhi besarnya bagian harga yang diterima oleh setiap pelaku. Menurut Febriani (2013), beberapa faktor yang dipertimbangkan dalam memilih saluran pemasaran yaitu:

1. Pertimbangan pasar yang meliputi konsumen akhir dengan melihat pembeli potensial, konsentrasi pasar secara geografis, volume pesanan, dan kebiasaan pembeli.

2. Pertimbangan barang yang meliputi nilai barang per unit, besar, berat, tingkat kerusakan, dan sifat teknis barang untuk memenuhi pesanan atau pasar.

3. Pertimbangan internal perusahaan yang meliputi sumber permodalan, pengawasan, penyaluran, pelayanan, dan pengalaman penjualan.

4. Pertimbangan terhadap lembaga pemasaran yang meliputi pelayanan lembaga pemasaran, kesesuaian lembaga pemasaran dengan kebijaksanaan perusahaan, dan pertimbangan biaya. 


\section{b. Analisis Marjin}

Marjin pemasaran dihitung berdasarkan pengurangan harga penjualan dengan harga pembelian pada setiap tingkat lembaga pemasaran. Besarnya marjin pemasaran pada dasarnya juga merupakan penjumlahan dari biaya-biaya pemasaran dan keuntungan yang diperoleh lembaga pemasaran. Secara matematis dirumuskan:

$$
\begin{gathered}
\mathrm{M}_{\mathrm{i}}=\mathrm{P}_{\mathrm{si}}-\mathrm{P}_{\mathrm{bi}} \\
\mathrm{M}_{\mathrm{i}}=C_{\mathrm{i}}+\pi_{\mathrm{i}}
\end{gathered}
$$

Keterangan:

$\mathrm{M}_{\mathrm{i}}=$ marjin pemasaran lembaga pemasaran tingkat ke $-\mathrm{i}\left(\mathrm{Rp} / \mathrm{m}^{3}\right)$

$\mathrm{P}_{\mathrm{si}}=$ harga penjualan lembaga pemasaran tingkat $\mathrm{ke}-\mathrm{i}$ $\left(\mathrm{Rp} / \mathrm{m}^{3}\right)$

$\mathrm{P}_{\mathrm{bi}}=$ harga pembelian lembaga pemasaran tingkat ke $\mathrm{i}\left(\mathrm{Rp} / \mathrm{m}^{3}\right)$

$\mathrm{C}_{\mathrm{i}}$ = biaya pemasaran lembaga pemasaran tingkat ke $\mathrm{i}\left(\mathrm{Rp} / \mathrm{m}^{3}\right)$

$\pi_{\mathrm{i}}=$ keuntungan pemasaran lembaga pemasaran tingkat ke $-\mathrm{i}\left(\mathrm{Rp} / \mathrm{m}^{3}\right)$.

\section{c. Analisis efisiensi pemasaran dan farmer's share}

Efisiensi pemasaran dapat diketahui dari rasio K/B (keuntungan terhadap biaya-biaya pemasaran) pada masing-masing lembaga pemasaran. Rasio K/B (keuntungan terhadap biaya-biaya pemasaran) dirumuskan:

$$
\text { Rasio Keuntungan/Biaya }=\frac{\pi_{\mathrm{i}}}{\mathrm{C}_{\mathrm{i}}}
$$

Besar kecilnya rasio K/B (keuntungan terhadap biaya-biaya pemasaran) belum tentu dapat menggambarkan efisiensi pemasaran, sehingga indikator lain yang digunakan adalah memperbandingkan bagian harga yang diterima oleh petani (farmer's share).

Farmer's share merupakan bagian pendapatan yang diterima petani dari kegiatan pemasaran. Analisis farmer's share digunakan untuk membandingkan persentase dari harga yang dibayar konsumen terhadap harga yang diterima petani (Limbong et al. 1985 dalam Febriani 2013). Semakin tinggi harga yang diterima konsumen dari lembaga pemasaran (pedagang), maka persentase yang diterima oleh petani semakin sedikit. Hal ini dikarenakan adanya hubungan negatif antara marjin pemasaran dengan bagian yang diterima petani. Secara matematis farmer's share dihitung sebagai berikut:

$$
F_{s}=\frac{P_{f}}{P_{r}} \times 100 \%
$$

Keterangan:

$\mathrm{F}_{\mathrm{s}}=$ persentase yang diterima petani dari harga konsumen akhir

$\mathrm{P}_{\mathrm{f}} \quad=$ harga di tingkat petani

$\mathrm{P}_{\mathrm{r}} \quad=$ harga di tingkat konsumen akhir

\section{HASIL DAN PEMBAHASAN}

\section{Karakteristik Responden}

Pelaku pemasaran kayu hutan rakyat yang menjadi responden dalam penelitian ini meliputi petani hutan rakyat, pedagang pengumpul, dan pemilik industri penggergajian (sawmill) yang ada di Kecamatan Leuwisadeng, Cigudeg, dan Jasinga. Berikut uraian karakteristik dari masing-masing pelaku pemasaran yang terkait.

Berdasarkan umur, mayoritas responden $(73 \%)$ berusia di atas 40 tahun, berdasarkan hasil penelitian ini diperoleh data bahwa generasi muda di lokasi penelitian kurang tertarik untuk berusaha di bidang hutan rakyat karena dianggap kurang menjanjikan masa depan. Tingkat Pendidikan responden relatif rendah dimana $86,67 \%$ persen memiliki tingkat Pendidikan sekolah dasar (SD), lebih rendah dari rata-rata lama sekolah di Kabupaten Bogor yaitu 8.15 tahun (BPS Provinsi Jawa Barat, 2018). Penyebab utama rendahnya tingkat Pendidikan adalah motivasi, faktor ekonomi dan faktor jarak tempuh sekolah yang jauh dari tempat tinggal petani.

\section{Pendapatan}

Sebagian besar pendapatan petani responden setiap bulannya masih tergolong rendah dan di bawah UMK Kabupaten maupun Kota Bogor tahun 2015. Pendapatan petani dari hutan rakyat baik dari hasil hutan kayu maupun hasil hutan bukan kayu memiliki konstribusi sebesar $17.97 \%$ dari penghasilan total petani setiap bulannya. Persentase pendapatan petani berdasarkan kelas pendapatan dan rekapitulasi asal pendapatannya dapat dilihat pada Tabel 1 dan Tabel 2.

Tabel 1 Karakteristik petani responden berdasarkan kelas pendapatan per bulan

\begin{tabular}{lcccc}
\hline \multirow{2}{*}{ Kecamatan } & \multicolumn{3}{c}{ Pendapatan (Rp) } & Jumlah \\
\cline { 2 - 4 } & 1 & 2 & 3 & (orang) \\
\hline Leuwisadeng & 8 & 0 & 2 & 10 \\
$\begin{array}{l}\text { Cigudeg } \\
\text { Jasinga }\end{array}$ & 7 & 0 & 3 & 10 \\
\hline $\begin{array}{l}\text { Jumlah } \\
\text { (orang) }\end{array}$ & 19 & 0 & 6 & 10 \\
\hline $\begin{array}{l}\text { Persentase } \\
(\%)\end{array}$ & 63.33 & 0.00 & 36.67 & 100 \\
\hline
\end{tabular}

Keterangan: 1: < Rp2 242 240; 2: Rp2 242 240-Rp2

352 350; 3: > Rp2 352350

Sumber: data primer (Diolah)

Tabel 2 Rekapitulasi asal pendapatan petani hutan rakyat

\begin{tabular}{lccc}
\hline \multirow{2}{*}{ Kecamatan } & \multicolumn{2}{c}{ Asal pendapatan } & \\
\cline { 2 - 3 } & $\begin{array}{c}\text { Non hutan } \\
\text { rakyat (\%) }\end{array}$ & $\begin{array}{c}\text { Hutan } \\
\text { rakyat } \\
(\%)\end{array}$ & $\begin{array}{c}\text { Jumlah } \\
(\%)\end{array}$ \\
\hline Leuwisadeng & 88.90 & 11.10 & 100 \\
Cigudeg & 85.89 & 14.11 & 100 \\
Jasinga & 71.29 & 28.71 & 100 \\
\hline Rata-rata (\%) & 82.03 & 17.97 & 100 \\
\hline
\end{tabular}

Sumber: data primer (diolah) 


\section{Luas Rata-Rata Hutan Rakyat}

Setiap lokasi penelitian memiliki luasan hutan rakyat yang berbeda-beda. Data pada Tabel 6 menunjukkan bahwa Kecamatan Jasinga merupakan kecamatan dengan luas rata-rata hutan rakyat terluas yaitu 1.60 hektar dan menyusul Kecamatan Cigudeg dan Leuwisadeng. Luas minimal, maksimal, dan rata-rata hutan rakyat di lokasi penelitian disajikan pada Tabel 3.

\section{Bentuk Penjualan Kayu}

Petani hutan rakyat menjual kayu hutan rakyat dalam 3 bentuk, yaitu dalam bentuk pohon berdiri, kayu bulat, dan kombinasi (kayu gergajian atau balken/balok kayu dan kayu bulat). Dalam bentuk penjualan kayu secara kombinasi, kayu akan dibentuk balken apabila kayu berdiameter besar sedangkan jika berdiameter kecil atau sedang dijual dalam bentuk kayu bulat. Menurut responden yang diwawancarai, menjual kayu dalam bentuk balken lebih menguntungkan dibandingkan dengan menjual kayu dalam bentuk kayu bulat saja. Bentuk penjualan kayu oleh petani responden di lokasi penelitian dapat dilihat pada Tabel 4 .

Banyaknya petani yang menjual kayu hutan rakyatnya dalam bentuk pohon berdiri membuat hasil penjualan kayu kurang optimal karena tidak memperoleh nilai tambah. Hal ini dikarenakan beberapa faktor penghambat seperti kurangnya modal yang dimiliki petani untuk menjual pohon dalam bentuk kayu bulat, jumlah pohon yang akan ditebang pada setiap tahunnya terbatas, serta kurangnya informasi dan akses petani terhadap pasar.

\section{Sistem Penjualan Kayu dan Sistem Penebangan}

Terdapat 3 sistem penjualan kayu yang dilakukan oleh para petani yaitu per pohon, borongan, dan per kubikasi (Tabel 5), sedangkan sistem penebangan yang

Tabel 5 Luas minimal, maksimal, dan rata-rata hutan rakyat pada masing-masing kecamatan lokasi penelitian

\begin{tabular}{lrrr}
\hline Kecamatan & $\begin{array}{r}\text { Luas } \\
\text { minimal } \\
\text { (ha) }\end{array}$ & $\begin{array}{r}\text { Luas } \\
\text { maksimal } \\
\text { (ha) }\end{array}$ & $\begin{array}{r}\text { Luas rata- } \\
\text { rata hutan } \\
\text { rakyat (ha) }\end{array}$ \\
\hline Leuwisadeng & 0.30 & 1 & 0.54 \\
Cigudeg & 0.45 & 2 & 0.85 \\
Jasinga & 0.50 & 4 & 1.60 \\
\hline Total (ha) & 1.25 & 7 & 2.99 \\
\hline
\end{tabular}

Sumber: data primer

Tabel 6 Persentase bentuk penjualan kayu oleh responden petani hutan rakyat

\begin{tabular}{lrrrr}
\hline \multirow{2}{*}{ Kecamatan } & \multicolumn{3}{c}{ Bentuk penjualan kayu } & Jumlah \\
\cline { 2 - 4 } & $\begin{array}{r}\text { Pohon } \\
\text { berdiri }\end{array}$ & $\begin{array}{r}\text { Kayu } \\
\text { bulat }\end{array}$ & Kombinasi & (orang) \\
\hline Leuwisadeng & 9 & 1 & 0 & 10 \\
Cigudeg & 9 & 0 & 1 & 10 \\
Jasinga & 10 & 0 & 0 & 10 \\
\hline $\begin{array}{l}\text { Jumlah } \\
\text { (orang) }\end{array}$ & 28 & 1 & 1 & 30 \\
\hline $\begin{array}{l}\text { Persentase } \\
(\%)\end{array}$ & 93.33 & 3.33 & 3.33 & 100 \\
\hline Sumber: data primer (diolah)
\end{tabular}

Sumber: data primer (diolah) dilakukan adalah tebang habis dan tebang pilih (Tabel 6). Sistem penjualan tebang pilih sering dikenal juga dengan sistem penjualan tebang butuh. Disebut tebang butuh karena pada kenyataannya pohon-pohon tersebut lebih dianggap tabungan oleh pemiliknya dan tidak akan dijual sebelum ada keperluan yang mendesak. Petani biasanya menjual pohonnya saat membutuhkan biaya untuk sekolah anak ataupun ada acara yang sangat penting seperti menikahkan anak atau acara lainnya.

Sistem tebang pilih tidak selalu disebut dengan sistem tebang butuh, hal ini dikarenakan beberapa petani memang secara rutin menjual kayu hasil dari kebunnya yang sudah layak tebang (dipilih) pada setiap tahun (walaupun tidak dalam kondisi butuh). Sistem penjualan per pohon biasanya digunakan oleh petani responden yang menggunakan sistem penebangan tebang pilih, namun ada juga petani yang menjual kayunya dengan sistem penjualan kubikasi walaupun menggunakan sistem tebang pilih. Untuk petani responden yang menggunakan sistem tebang habis (umur pohon 2-6 tahun), biasanya sistem penjualan yang dilakukan adalah borongan yaitu menjual semua kayu rakyat yang ada di kebun selain pohon buah dan karet. Berikut disajikan sistem penjualan kayu dan sistem penebangan yang digunakan oleh petani responden.

\section{Analisis Saluran Pemasaran}

Analisis saluran pemasaran digunakan untuk mengetahui aliran barang dari produsen ke konsumen, sehingga dapat digunakan untuk mengidentifikasi lembaga pemasaran yang terlibat dalam proses pemindahan kayu hutan rakyat dari produsen (petani) hingga ke konsumen di ketiga kecamatan lokasi penelitian. Menurut Kotler dan Armstrong (2008),

Tabel 3 Sistem penjualan kayu hutan rakyat oleh petani

\begin{tabular}{lrrrr}
\multicolumn{3}{c}{ responden } & \multicolumn{3}{c}{ Sistem penjualan kayu } & Jumlah \\
\cline { 2 - 4 } & $\begin{array}{c}\text { Per } \\
\text { pohon }\end{array}$ & Borongan & Kubikasi & (orang) \\
\hline Leuwisadeng & 9 & 0 & 1 & 10 \\
Cigudeg & 3 & 6 & 1 & 10 \\
Jasinga & 5 & 5 & 0 & 10 \\
\hline Jumlah & 17 & 11 & 2 & 30 \\
(orang) & & & & \\
\hline Persentase & 56.67 & 36.67 & 6.67 & 100 \\
\hline (\%) & & & &
\end{tabular}

Sumber: data primer (Diolah)

Tabel 4 Persentase sistem penebangan yang digunakan oleh petani responden

\begin{tabular}{lrrr}
\hline \multirow{2}{*}{ Kecamatan } & \multicolumn{2}{c}{ Sistem penebangan } & \\
\cline { 2 - 3 } & $\begin{array}{r}\text { Tebang } \\
\text { habis }\end{array}$ & $\begin{array}{r}\text { Tebang } \\
\text { pilih }\end{array}$ & $\begin{array}{r}\text { Jumlah } \\
\text { (orang) }\end{array}$ \\
\hline Leuwisadeng & 0 & 10 & 10 \\
Cigudeg & 6 & 4 & 10 \\
Jasinga & 5 & 5 & 10 \\
\hline Jumlah & 11 & 19 & 30 \\
(orang) & 36.67 & 63.33 & 100 \\
\hline Persentase & $\%$ ) & &
\end{tabular}

Sumber: data primer (Diolah) 
saluran pemasaran (saluran distribusi) merupakan sekelompok organisasi yang saling tergantung yang membantu membuat produk atau jasa tersedia untuk digunakan atau dikonsumsi oleh konsumen atau pengguna bisnis.

Kotler (2005) dalam Ratnaningrum (2009) mengatakan bahwa saluran pemasaran dapat dicirikan dengan memperhatikan banyaknya tingkat saluran. Panjangnya suatu saluran tataniaga/pemasaran akan ditentukan oleh banyaknya tingkat perantara yang dilalui oleh suatu barang atau jasa. Saluran pemasaran tersebut meliputi:

a) Saluran non tingkat (Zero-level-channel) atau dinamakan sebagai saluran pemasaran langsung, adalah saluran di mana produsen atau pabrikan langsung menjual produknya ke konsumen.

b) Saluran 1 tingkat (One-level-channel) adalah saluran yang menggunakan perantara.

c) Saluran 2 tingkat (Two-level-channel) mencakup 2 perantara.

d) Saluran 3 tingkat (Three-level-channel) mencakup 3 perantara.

Saluran pemasaran dapat berbentuk secara sederhana dan dapat pula rumit sekali. Hal demikian tergantung dari macam komoditi, lembaga pemasaran dan sistem pasar. Sistem pasar yang monopoli mempunyai saluran pemasaran yang relatif sederhana dibandingkan dengan sistem pasar yang lain (Soekartawi, 2002).

Saluran pemasaran kayu hutan rakyat di Kecamatan Leuwisadeng, Cigudeg, dan Jasinga dari petani ke industri penggergajian (sawmill) relative sederhana dimana hanya melibatkan 3 pihak, yaitu petani, pedagang pengumpul dan industri sawmill (Gambar 1).

Gambar 1 menginformasikan bahwa saluran pemasaran kayu hutan rakyat mempunyai 2 saluran, yaitu dari petani hutan rakyat menuju pedagang pengumpul kemudian ke industri sawmill (93.33\%) dan dari petani hutan rakyat langsung menuju industri sawmill $(6.67 \%)$. Dilihat dari jarak penyaradan kayu rakyat dari tunggak menuju TPn, saluran pemasaran di lokasi penelitian dapat dibedakan menjadi 2 yaitu jarak dekat ( $<$ dari 500 meter) dan jauh (> 500 meter).

\section{Saluran I (Petani - Industri Penggergajian (jauh))}

Pada saluran I, petani hutan rakyat menjual secara langsung kayu hasil panennya kepada industri sawmill

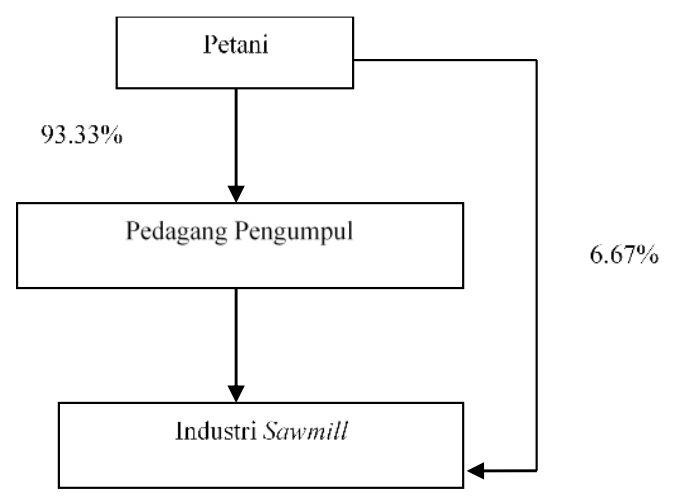

Gambar 1Saluran pemasaran kayu hutan rakyat di lokasi penelitian dengan jarak penyaradan yang tergolong jauh. Pada penelitian yang dilakukan, responden yang melakukan saluran pemasaran seperti saluran I hanya ada 1 orang $(3.33 \%)$. Pada saluran ini, responden menjual kayu rakyatnya dalam bentuk balken (kayu gergajian) yang berukuran $10 \mathrm{~cm}$ × $20 \mathrm{~cm}$ × $2.8 \mathrm{~m}$ dengan harga sebesar Rp 40000 per balken. Pada saluran ini, biaya penebangan, penyaradan dan pemuatan, serta pengangkutan ke industri penggergajian ditanggung oleh petani. Dalam saluran ini petani menjual kayunya dalam bentuk balken yang memiliki ukuran pasti, dengan demikian industri penggergajian pada umumnya akan membentuk kayu ini menjadi papan dengan ukuran $2 \mathrm{~cm}$ x $20 \mathrm{~cm}$ x $2.8 \mathrm{~m}$. Menjual kayu dalam bentuk papan memiliki harga jual yang lebih tinggi dibandingkan dengan bentuk kayu pertukangan lainnya karena telah memiliki nilai tambah. Menjual kayu dalam bentuk papan memerlukan ketelitian dalam prose pemotongan, karena jika terjadi kesalahan, jumlah papan yang dihasilkan tidak akan sesuai dengan perhitungan yang sudah ditentukan.

Pada prinsipnya, menjual kayu dalam bentuk balken lebih menguntungkan baik untuk petani maupun bagi industri penggergajian. Bagi petani, menjual kayu dalam bentuk balken mampu meningkatkan harga jual kayu dibandingkan dengan mejual dalam bentuk pohon berdiri dan bagi industri penggergajian, membeli kayu dalam bentuk balken lebih menguntungkan karena akan mendapatkan volume kayu yang pasti, meningkatkan produktivitas penggergajian, serta dapat meminimalkan biaya operasional.

\section{Saluran II (Petani - Industri Penggergajian (dekat))}

Tidak berbeda jauh dengan saluran I, pada saluran pemasaran II petani menjual kayunya secara langsung kepada industri sawmill. Saluran ini merupakan saluran non tingkat (zero level channel) atau saluran pemasaran tanpa melalui perantara seperti halnya saluran pemasaran I. Hanya saja yang membedakan di antara kedua saluran pemasaran ini adalah jarak sarad. Pada saluran pemasaran II jarak sarad tergolong dekat dan petani menjual kayunya dalam bentuk kayu bulat. Terdapat 1 orang responden $(3.33 \%)$ yang melakukan saluran pemasaran seperti ini. Hal ini dikarenakan responden memiliki pekerjaan utama sebagai dagang tani (bertani sekaligus menjadi pedagang pengumpul), sehingga disamping sebagai petani, pekerjaan utama responden ini adalah pedagang pengumpul kayu. Dalam saluran ini, kegiatan penebangan, penyaradan dan pemuatan, serta pengangkutan seluruh biayanya ditanggung sendiri oleh petani.

Bagi responden yang berprofesi sebagai dagang tani, menjual kayu dalam bentuk kayu bulat bukanlah hal yang sulit karena petani telah memiliki akses yang mudah, baik dalam penyediaan tenaga buruh harian maupun akses pasar. Menjual kayu dalam bentuk kayu bulat jelas lebih menguntungkan karena telah memiliki nilai tambah, terlebih jika hutan rakyat yang dimiliki memiliki tingkat aksesibilitas yang mudah seperti yang terjadi pada saluran pemasaran II, sehingga biaya operasional untuk pengangkutan serta penyaradan dan pemuatan dapat diminimalkan. Bagi industri penggergajian, 
membeli kayu dalam bentuk kayu bulat memang membutuhkan biaya operasional yang lebih besar jika dibandingkan dengan membeli balken, namun keuntungan lain yang didapatkan dengan membeli kayu bulat adalah kayu pertukangan (racuk) yang sering dianggap sebagai kayu sisa, serbuk kayu, dan kulit kayu.

\section{Saluran III (Petani - Pedagang Pengumpul - Industri Penggergajian (jauh))}

Saluran pemasaran III merupakan saluran satu tingkat I (one level channel) dengan jarak penyaradan yang tergolong jauh. Petani responden yang memiliki saluran ini berjumlah 18 orang $(60.00 \%)$, jumlah ini merupakan jumlah yang terbanyak jika dibandingkan dengan saluran pemasaran yang lainnya. Pada saluran pemasaran ini, petani tidak dibebani biaya-biaya operasional dikarenakan semua biaya operasional telah ditanggung oleh pedagang pengumpul. Bentuk penjualan kayu yang dilakukan oleh petani adalah pohon berdiri, karena lokasi tebangan dan TPn jauh maka harga yang diterima petani tergolong rendah.

Pada saluran ini, biasanya pengumpul kayu menjual kayu dari petani kepada industri penggergajian berupa kayu bulat. Dengan jarak penyaradan yang jauh, maka untuk biaya operasional penyaradan dan pemuatan dibedakan, hal inilah yang menyebabkan biaya operasionalnya tinggi. Karena pemasaran kayu hanya terbatas dalam 1 kecamatan maka biaya pengangkutan pun tidak begitu besar.

\section{Saluran IV (Petani - Pedagang Pengumpul - Industri Penggergajian (dekat))}

Sama halnya dengan saluran pemasaran III, saluran pemasaran IV merupakan saluran 1 tingkat, yang membedakan di antara kedua saluran ini adalah jarak penyaradan kayu. Dikarenakan jarak penyaradan kayu dari tunggak menuju ke TPn dekat maka buruh harian yang bekerja sebagai tenaga sarad juga merangkap pekerjaannya sebagai buruh muat kayu. Selain itu, yang membedakan dari saluran III dan IV ini adalah harga jual kayu yang didapatkan oleh petani. Petani di saluran IV mendapatkan harga jual kayu yang lebih tinggi dibandingkan dengan saluran III. Dengan demikian, aksesibilitas dan bentuk penjualan kayu merupakan faktor yang berpengaruh penting terhadap harga jual kayu.

\section{Analisis Marjin Pemasaran}

Analisis marjin pemasaran merupakan salah satu indikator untuk mengetahui besarnya biaya yang dikeluarkan setiap lembaga dalam suatu saluran pemasaran mulai dari tingkat petani sampai ke konsumen. Menurut Ratnaningrum (2009), marjin pemasaran merupakan perbedaan harga yang diterima oleh produsen dengan harga yang dibayarkan oleh konsumen. Nilai marjin pemasaran dibentuk oleh keuntungan pemasaran yang diperoleh dan biaya pemasaran yang dikeluarkan. Besar kecilnya biaya, keuntungan, dan marjin pemasaran produk dapat dilihat pada Tabel 7.

Data pada Tabel 7 menunjukkan bahwa marjin pemasaran tertinggi diterima oleh pedagang pengumpul pada saluran III $(41.10 \%)$. Pada saluran ini, petani menjual kayu rakyat kepada pedagang pengumpul dalam bentuk pohon berdiri dengan jarak sarad yang tergolong jauh, sedangkan marjin pemasaran terkecil diterima oleh industri penggergajian pada saluran III dan IV. Pada kedua saluran ini, biaya operasional, pembelian kayu, dan penjualan kayu pada setiap industri cenderung sama sehingga marjin yang didapatkan oleh industri pada kedua saluran ini sama. Menurut Nurtjahjadi (1997), faktor yang mempengaruhi besar kecilnya marjin pemasaran adalah perubahan biaya pemasaran, keuntungan dari perantara, harga yang dibayarkan oleh konsumen dan harga yang diterima petani produsen, sifat barang yang diperdagangkan dan tingkat pengolahan barang.

Pada saluran III, besarnya marjin yang diterima oleh pedagang pengumpul disebabkan oleh besarnya keuntungan yang didapatkan oleh pedagang pengumpul. Jauhnya aksesibilitas kayu rakyat milik petani menjadi alasan para pedagang pengumpul untuk mendapatkan kayu rakyat dengan harga murah, padahal jika dibandingkan dengan biaya operasional pada kayu yang aksesibilitasnya mudah hanya selisih $3.20 \%$ namun keuntungan yang didapakan selisih $9.51 \%$.

Biaya pemasaran merupakan seluruh biaya yang dikeluarkan dalam proses pembuatan dan penyampaian barang, mulai dari tingkat produsen hingga konsumen. Pada penelitian ini, biaya pemasaran terdiri dari biaya penebangan, penyaradan, pemuatan, pengangkutan, upah tenaga kerja penggergajian, konsumsi, tali rafia dan listrik, serta biaya pembuatan SKSHH.

Kegiatan penebangan serta penyaradan dan pemuatan merupakan kegiatan yang membutuhkan biaya besar dibandingkan dengan biaya pemasaran lainnya. Kegiatan-kegiatan tersebut dalam seluruh saluran pemasaran yang ada dilakukan oleh pedagang pengumpul ataupun petani (juga berprofesi sebagai pedagang pengumpul). Untuk kegiatan penebangan yang menggunakan chainsaw, pedagang pengumpul biasanya tidak memiliki chainsaw sendiri hal ini dikarenakan kurangnya modal yang dimiliki oleh pedagang pengumpul sehingga alternatif yang mudah adalah menyewa chainsaw beserta operator dan bahan bakarnya. Harga sewa chainsaw dalam sehari berkisar Rp300 000

Tabel 7 Marjin dan farmer's share masing-masing saluran pemasaran

\begin{tabular}{|c|c|c|c|c|c|c|c|c|}
\hline \multirow{2}{*}{$\begin{array}{c}\text { Saluran } \\
\text { pemasaran }\end{array}$} & \multirow{2}{*}{$\begin{array}{c}\text { Petani } \\
\text { Farmer's share }\end{array}$} & \multicolumn{3}{|c|}{ Pedagang pengumpul } & \multicolumn{3}{|c|}{ Industri penggergajian } & \multirow{2}{*}{$\begin{array}{c}\text { Total } \\
\text { rasio K/B }\end{array}$} \\
\hline & & Biaya & $\pi$ & Marjin & Biaya & $\Pi$ & Marjin & \\
\hline 1 & 46.42 & - & - & - & 7.15 & 23.28 & 30.43 & 5.26 \\
\hline 2 & 46.93 & - & - & - & 9.01 & 25.87 & 34.88 & 5.45 \\
\hline 3 & 30.55 & 20.10 & 21.01 & 41.10 & 8.21 & 18.72 & 26.93 & 24.84 \\
\hline 4 & 44.25 & 16.90 & 10.50 & 27.40 & 8.21 & 18.72 & 26.93 & 34.06 \\
\hline
\end{tabular}

Sumber: data diolah

Keterangan: $\pi=$ keuntungan 
hingga Rp350 000 dengan produktivitas rata-rata chainsaw adalah $5 \mathrm{~m}^{3} /$ alat/hari.

Kegiatan lain yang membutuhkan biaya yang besar adalah penyaradan dan pemuatan. Kegiatan ini dilakukan dengan menggunakan tenaga manusia karena tidak memungkinkan dilakukan dengan tenaga mesin. Selain karena volume kayu yang terlalu kecil, keberadaan hutan rakyat di tengah-tengah pemukiman masyarakat membuat tidak sedikit masyarakat yang menggantungkan hidupnya pada keberadaan hutan tersebut. Selain fungsi ekologi seperti ketersediaan air dan udara, fungsi sosial dari hutan rakyat memegang peranan penting bagi masyarakat sekitar sebagai sumber mata pencahariaan dan tidak terkecuali bagi para masyarakat sekitar hutan yang bekerja sebagai buruh harian. Karena dikerjakan dengan tenaga manusia, biaya operasional penyaradan dan pemuatan menjadi mahal. Terlebih untuk hutan yang jauh dengan tepi jalan, biasanya buruh sarad dan muat dibedakan sehingga biaya operasional lebih mahal.

Khusus saluran pemasaran I, biaya pengangkutan adalah biaya yang paling tinggi. Hal ini dikarenakan pada saluran I jarak angkut yang ditempuh cukup jauh walaupun masih dalam satu kecamatan. Aksesibilitas yang sulit membuat biaya pengangkutan pun semakin mahal.

\section{Analisis Efisiensi Pemasaran dan Farmer's Share}

Efisiensi saluran pemasaran dapat dilihat berdasarkan marjin pemasaran, nilai farmer's share, dan biaya pemasaran. Saluran yang efisien adalah saluran pemasaran yang dapat memperoleh keuntungan yang besar dengan pengorbanan biaya yang kecil. Menurut Soekartawi (2002), beberapa faktor yang dapat dipakai sebagai ukuran efisiensi pemasaran, yaitu keuntungan pemasaran, harga yang diterima konsumen, tersedianya fasilitas fisik pemasaran, dan kompetisi pasar.

Besarnya rasio K/B (keuntungan terhadap biaya pemasaran) pada pemasaran kayu rakyat di lokasi penelitian berkisar antara 5.26 sampai 34.06. Nilai total rasio K/B 5.26 berarti setiap Rp1 biaya yang dikeluarkan akan memperoleh keuntungan Rp5.26. Di tingkat pedagang pengumpul, rasio K/B pada saluran III (1.05) lebih besar daripada saluran IV (0.62), hal ini menandakan bahwa keuntungan yang diperoleh pedagang pengumpul saluran III lebih besar dibandingkan dengan biaya pemasaran yang dikeluarkan. Sedangkan di tingkat industri penggergajian, rasio $\mathrm{K} / \mathrm{B}$ terbesar berada di saluran I (3.26). Hal ini dikarenakan pada saluran I industri penggergajian mengambil bahan baku dari petani berupa balken sehingga biaya operasional yang dikeluarkan tidak sebesar pada saluran pemasaran lainnya. Jika dibandingkan dengan total rasio $\mathrm{K} / \mathrm{B}$, saluran yang memiliki total rasio $\mathrm{K} / \mathrm{B}$ tertinggi adalah saluran IV sehingga jika hanya dilihat dari analisis rasio $\mathrm{K} / \mathrm{B}$, saluran IV merupakan saluran yang paling efektif. Namun besar kecilnya rasio K/B (keuntungan terhadap biaya-biaya pemasaran) belum tentu dapat menggambarkan efisiensi pemasaran, sehingga indikator lain yang digunakan adalah memperbandingkan bagian harga yang diterima oleh petani (farmer's share).
Farmer's share menggambarkan tingginya harga yang didapat di tingkat petani, sehingga saluran yang paling menguntungkan bagi petani adalah saluran yang memiliki farmer's share paling tinggi. Farmer's share memiliki hubungan negatif dengan marjin pemasaran, artinya semakin besar marjin pemasaran maka bagian yang diterima oleh petani semakin kecil.

Saluran pemasaran yang memiliki nilai farmer's share tertinggi di lokasi penelitian adalah saluran I (69.57\%). Namun jika farmer's share yang dibandingkan adalah farmer's share yang telah dikurangi dengan biaya operasional yang dikeluarkan oleh petani, saluran II merupakan saluran pemasaran yang paling efisien. Hal ini dikarenakan kayu pada saluran I memiliki aksesibilitas yang sulit dan mengakibatkan bertambahnya biaya operasional yang harus dikeluarkan oleh petani sehingga harga bersih yang diterima oleh petani juga menjadi lebih kecil.

Nilai farmer's share terkecil berada di saluran III, hal ini dikarenakan pada saluran itu terdapat 3 pelaku pemasaran yang meliputi petani, pedagang pengumpul, dan industri penggergajian, sehingga keuntungan yang didapat oleh petani dan industri penggergajian lebih kecil jika dibandingkan dengan saluran pemasaran tanpa melalui perantara (pedagang pengumpul). Selain itu, aksesibilitas kayu rakyat pada saluran III ini tergolong jauh sehingga biaya operasional yang dibutuhkan semakin besar. Berbeda dengan saluran IV, walaupun pada saluran ini terdapat pedagang perantara, namun karena biaya operasional yang dibutuhkan untuk mengeluarkan kayu mulai dari tunggak ke pinggir jalan relatif dekat dan mudah, maka biaya operasional penyaradan dan pemuatan juga relatif lebih murah.

Saluran pemasaran akan lebih efisien apabila petani melakukan penjualan kayu dalam bentuk kayu gergajian (balken) secara langsung ke industri penggergajian dengan aksesibilitas kayu yang mudah. Upaya lain yang dapat dilakukan untuk meningkatkan harga jual kayu rakyat adalah dengan membentuk organisasi petani berupa kelompok tani atau unit usaha bersama seperti koperasi yang mampu menjadi wadah untuk menyalurkan kayu rakyat secara langsung dari petani ke konsumen sehingga harga jual kayu dapat lebih maksimal. Selain itu, koperasi ini hendaknya dapat memberikan pinjaman kepada petani dengan jaminan pohon yang dimiliki petani jika sewaktu-waktu petani membutuhkan uang sehingga petani tidak menjual kayu pada umur pohon yang kurang dan membuat harga jual kayu di bawah rata-rata.

Peran pemerintah khususnya lembaga penyuluh kehutanan juga sangat diperlukan untuk memfasilitasi pelatihan dan penyuluhan mengenai pelatihan organisasi, pelatihan mengenai jaringan pemasaran dan informasi pasar, serta pembinaan dan pendampingan organisasi. Dengan adanya informasi pasar yang jelas, petani dapat mengetahui besarnya harga jual kayu yang sesungguhnya sehingga petani dapat membadingkan sistem penjualan yang lebih menguntungkan petani. 


\section{SIMPULAN DAN SARAN}

\section{Simpulan}

Berdasarkan hasil penelitian dapat disimpulkan bahwa pelaku pemasaran kayu rakyat di lokasi penelitian terdiri dari petani hutan rakyat, pedagang pengumpul, dan industri penggergajian (sawmill). Jenis kayu yang banyak diminati oleh pasar dan petani adalah jenis sengon, karena merupakan jenis pohon yang memiliki umur panen yang relatif singkat, mudah tumbuh, pembudidayaannya mudah, dan memiliki harga jual yang menggiurkan. Menurut konsumen, harga sengon relatif terjangkau, kayu tidak mudah keropos, dan banyak tersedia di pasaran.

Berdasarkan pelakunya, saluran pemasaran kayu rakyat di lokasi penelitian terdiri dari 2 saluran. Jika dikelompokkan lagi berdasarkan jarak sarad rata-rata kayu rakyat, saluran yang terbentuk menjadi 4 saluran. Diantara keempat saluran ini, saluran yang paling efisien adalah saluran pemasaran II. Pada saluran ini, petani menjual langsung kayu hutan rakyat ke industri penggergajian dalam bentuk kayu bulat sehingga memiliki nilai jual kayu yang lebih tinggi. Saluran II memiliki farmer's share sebesar $46.93 \%$ dengan rasio $\mathrm{K} / \mathrm{B}$ sebesar 5.45. Keuntungan terbesar pada saluran pemasaran tanpa perantara didapat oleh petani yaitu sebesar $46.93 \%$ (saluran II). Dalam pemasaran yang melibatkan perantara diantara petani dan industri penggergajian, pelaku pemasaran yang memperoleh keuntungan terbesar adalah pedagang pengumpul sebesar $41.10 \%$ (saluran III).

\section{Saran}

Sebaiknya petani menjual kayu hutan rakyat langsung kepada industri penggergajian dengan bentuk kayu gergajian (balken) yang sistem penjualan dan perhitungannya berdasarkan kubikasi kayu seperti pada saluran I. Petani hendaknya mampu membentuk organisasi seperti kelompok tani maupun koperasi yang mampu menjadi wadah untuk menyalurkan kayu rakyat secara langsung dari petani ke konsumen sehingga harga jual kayu dapat lebih maksimal. Untuk itu, diperlukan peran lembaga penyuluh kehutanan untuk memberikan pelatihan dan penyuluhan mengenai pelatihan organisasi, pelatihan mengenai jaringan pemasaran dan informasi pasar, serta pembinaan dan pendampingan organisasi sehingga petani mendapatkan informasi pasar yang benar.

\section{DAFTAR PUSTAKA}

Badan Pusat Statistik Kabupaten Bogor. 2014. Kabupaten Bogor dalam Angka Bogor Regency in Figures 2014 [Internet]. [diunduh 2014 September 26]. Tersedia pada: http://bogorkab.bps.go.id/publikasi/kabupatenbogor-dalam-angka-2014.

Departemen Kehutanan. 2007. Road Map Revitalisasi Industri Kehutanan Indonesia In-House Experts
Working Group Revitalisasi Industri Kehutanan. Jakarta (ID): Departemen Kehutanan.

Dinas Pertanian dan Kehutanan Kabupaten Bogor. 2012. Monografi Dinas Pertanian dan Kehutanan Kabupaten Bogor 2012. Bogor (ID): Dinas Pertanian dan Kehutanan Kabupaten Bogor.

Djajapertjuanda S dan Djamhuri E. 2013. Hutan dan Kehutanan Indonesia dari Masa ke Masa. Bogor (ID): IPB Press.

Febriani. 2013. Sistem pemasaran dan nilai tambah produk olahan ubi jalar (Ipomoea batatas 1.) di Desa Cikarawang dan Desa Petir, Kecamatan Dramaga, Kabupaten Bogor [Skripsi]. Bogor (ID): Institut Pertanian Bogor.

Hadi AQ dan Napitupulu RM. 2012. 10 Tanaman Investasi Pendulang Rupiah. Jakarta (ID): Penebar Swadaya.

Hardjanto. 2000. Beberapa Ciri Pengusahaan Hutan Rakyat di Jawa. Dalam Suharjito (penyunting). Hutan Rakyat di Jawa Perannya dalam Perekonomian Desa. Bogor (ID): Program Penelitian dan Pengembangan Kehutanan Masyarakat (P3KM).

Irawanti S, Suka AP \& Ekawati S. (2012). Manfaat Ekonomi dan Peluang Pengembangan Hutan Rakyat Sengon di Kabupaten Pati. Jurnal Penelitian Sosial dan Ekonomi Kehutanan, 9 (3): 126-139; DOI: 10.20886/jsek.2012.9.3.126-139

Kementerian Kehutanan. 2012. Statistik Kehutanan Indonesia 2011 [Internet]. [diunduh 2014 September 16]. Tersedia pada: http://www.dephut.go.id/uploads/files/BUKU\%2 0STATISTIK\%202012.pdf

Kotler P. (2005). Manajemen Pemasaran. Edisi kesebelas. Jilid 1. Jakarta: Indeks Mulia Pustaka, Jakarta

Kotler P dan Armstrong G. 2008. Prinsip-prinsip Pemasaran Jilid 2 Edisi 12. Bob Sabran, penerjemah. Jakarta (ID): Penerbit Erlangga. Terjemahan dari: Principles of Marketing, Twelfth Edition.

Limbong WH dan P Sitorus. 1985. Pengantar Tataniaga Pertanian. Jurusan- Jurusan Ilmu Sosial Ekonomi Pertanian. Fakultas Pertanian Institut Pertanian Bogor, Bogor.

Meryani N. 2008. Analisis usahatani dan tataniaga kedelai di Kecamatan Ciranjang, Kabupaten Cianjur, Jawa Barat [Skripsi]. Bogor (ID): Institut Pertanian Bogor.

Nurtjahjadi. 1997. Analisis ekonomi pengelolaan hutan rakyat ke arah pemanfaatan hutan secara ganda di Wilayah Krui, Lampung Barat [Tesis]. Bogor (ID): Institut Pertanian Bogor.

Ratnaningrum A. 2009. Studi distribusi keuntungan dalam pemasaran kayu rakyat (Kasus di Kecamatan Cibinong dan Kecamatan Tanggeung, Wilayah Cianjur Selatan Kecamatan Cianjur) [Skripsi]. Bogor (ID): Institut Pertanian Bogor.

Rosnawati E. 2004. Karakteristik pemasaran kayu hasil hutan rakyat di Cianjur Selatan (Kasus di Kecamatan Cibinong dan Sindangbarang) [Skripsi]. Bogor (ID): Institut Pertanian Bogor. 
Sari RR, Hairiah K, \& Suyanto, S. (2018). Karakteristik Hutan Rakyat Jati dan Sengon Serta Manfaat Ekonominya di Kabupaten Malang. Jurnal Ekonomi Pertanian dan Agribisnis (JEPA), Volume 2 Nomor 2 (2018): 129-137; ISSN: 26144670 (p), ISSN: 2598-8174 (e).

Soekartawi. 2002. Prinsip Dasar Ekonomi Pertanian Teori dan Aplikasi Edisi Revisi 2001. Jakarta (ID): PT Raja Grafindo Persada
Sukwika T, Darusman D, Kusmana C, \& Nurrochmat, D R. (2016). Evaluating the level of sustainability of privately managed forest in Bogor, Indonesia. Biodiversitas Journal of Biological Diversity, Vol. 17 No. 1 (2016); $\quad$ DOI https://doi.org/10.13057/biodiv/d170135. 